\title{
Z-SCORE AND P-SCORE FOR BANKRUPTCY FRAUD DETECTION: A CASE OF THE CONSTRUCTION SECTOR IN LATVIA
}

\author{
Julija LIODOROVA ${ }^{1 *}$, Irina VORONOVA (D) ${ }^{2}$ \\ ${ }^{1}$ Faculty of Business, Management and Economics, University of Latvia, 19 Raina Blvd., Riga, Latvia \\ ${ }^{2}$ Department of Innovation and Business Management, Riga Technical University, 6 Kalnciema Street, Riga, Latvia \\ *E-mail:kik@inbox.lv
}

\begin{abstract}
To protect investment and ensure repayment of payables, recent studies have focused on identifying the relationships between company bankruptcy and internal fraud. The P-score model that is based on the most popular Altman Z-score model has been developed to indicate the manipulation of financial statements.

Purpose of the study is to determinate the accuracy and the feasibility of P-score and Z-score models to detect fraudulent bankruptcy in regional conditions, based on reports of the Latvian construction companies that failed due to fraud, and during the verification of other known data.

Research methodology is based on the background studies of P-score testifying, applying this approach to the Latvian condition. The present study analyzes the behaviour of the two models in identifying distress and fraud. To testify the results of the study, the authors use the financial analysis methods, comparison, statistical and quantitative research methods.

Findings have shown the possibility of using the P-score and Z-score technique for bankruptcy fraud detection at the Latvian companies, based on the construction sector samples. The accuracy of the method is above $80 \%$.

Research limitations - acquisition a large amount of data on companies that are in the process of analytical studies on the recognition of their insolvency and having signs of fraud is not possible due to the confidentiality of information.

Practical implications - the results of the study may be applicable to the audit of the company, investment reliability assessment, partnership evaluation and economic examination to detect fraud.

Originality/Value of the study is the first test of practical implication of P-score model in Latvia and the Baltic countries on the samples of small and medium-sized construction companies. The authors propose improving the coefficients of the P-score model taking into account the requirements for financial statements in Latvia.
\end{abstract}

Keywords: bankruptcy fraud, P-score, Z-score, Latvia, construction.

JEL Classification: C30, G33, M42.

Conference topic: Contemporary Financial Management.

\section{Introduction}

According to the Central Statistical Bureau of Latvia (2018) and Latvian Construction Contractor Partnership report (2017), above 60000 employees work in the construction sector, which is the seventh employer in Latvia. The total value added of the construction sector is currently over EUR 1 billion a year while the sector intermediate consumption is three times higher and reaches around EUR 3-4 billion per year. The construction industry makes a good share of the national gross domestic product $-5.9 \%$ in $2017,251.6$ million taxes were paid, i.e., $2.8 \%$ of the income of the General Budget of Latvia. Construction is the top four sectors that provide cross-sectoral links.

In the period 2005-2008, the fastest-growing capital investment was in the building sub-sector, which grew by more than $300 \%$ over the period. Certainly, in all EU countries, the level of investment declined in 2010 compared to 2008. In spite of this fact, the increase in private investment and flow of the European Union funds into the economy contribute to the development of the construction industry after the crisis. In 2016-2018, the public investment and EU funds were 342-500 million; in 2016, non-financial investment in the real sector was the largest - amounted to EUR 633.7 million or 16.5\% of all total non-financial investment (Central Statistical Bureau of Latvia, 2018).

However, in recent years, some problems have also emerged: the persistently high shadow economy, the lack of qualified professionals, the misuse of procurement tenders, etc. According to Sauka's study (2018), the shadow 
economy in the construction sector was $35.2 \%$, but since 2015 it has fallen by almost $5 \%$. The official average salary in the construction sector - EUR 796 - is less than the average wage in the country as a whole - EUR 903. To get tenders, builders are willing to risk different activities, looking for ways to cut costs and earn. In the builders'opinion, the main cause of the shadow economy is the lack of volume. On the other hand, the situation is definitely changing for the better. The best-recognised innovations to combat the shadow economy are the electronic working time records and rejection of the lowest price in government tenders.

Unfortunately, the fraudulent actions by construction companies themselves are not uncommon too: the envelope wages and fictitious expenses are used to reduce the tax burden; expensive materials are replaced with cheap substandard ones to increase profit; the debt concealment, hidden agreements and corruption are used to win a trend. Thus, free competition is distorted reducing the business opportunities for honest entrepreneurs, as well as the quality of constructed facilities, suffer, causing concern about their reliability. According to the Report to the Nations by the Association of Certified Fraud Examiners (2018), the construction industry is one of the most corrupted sectors of economy; it is among the top largest losses from professional fraud, an average of USD 227 000; more popular fraud schemes are corruption $-42 \%$, billing $-37 \%$, expense reimbursements and noncash $-23 \%$.

The expansion of the construction industry can stimulate growth in the industries it attracts. Since the demand for construction depends on demand in other sectors of the economy, the construction sector can contribute to the economy if there is sufficient demand (Sartaputna \& Mietule, 2018). Volume and market structure of the construction product depends on economic development. If the economic situation in the country worsens, the construction of residential buildings is immediately reduced, followed by a reduction in the construction of commercial, industrial and infrastructure objects (Skribans \& Pocs, 2008). A study by Sartaputna and Mietule (2018) showed that the number of economically active recognised construction companies in 2016 compared to 2012 increased by $7.8 \%$ or 375 companies; at the same time, a slight increase in the number of excluded companies was observed. Skribans and Pocs' (2018) studies showed that the demand for construction products in Latvia would drop starting from 2026.

The financial distress of the companies is the most dangerous risk of losing investment, so prediction of failure is important for the company executives, auditors and investors themselves. Various bankruptcy prediction models have been developed. Altman's model has some modifications: Z-score model is intended to publicly traded companies; Z'-score model - to private firms; Z' '-score model is a modification of the Z'-score model, which does not include industry specifics. Shorin and Voronova (1998) developed the Altman's model modification for the Latvian companies, the accuracy of which is $67.0 \%$ (Scacun \& Voronova, 2018). Marcinkevičius and Kanapeckiene's study (2014) showed that the accuracy of bankruptcy prediction for 388 Lithuanian construction companies within a year to failure by Altman's model was $74.47 \%$. Mackevičius and Rakšteliene's study (2005) emphasised that forecast had to be carried out every year because the results of one year did not allow for a univocal conclusion.

Altman, Iwanicz-Drozdowska, Latinen and Suvas's study (2014) estimated the Z''-score model accuracy of above 2.6 million reports of non-financial limited liability companies, total assets of which exceeded EUR 100000 . Twenty-nine European companies were investigated, including all Baltic countries, and 3 non-European (the UK, USA, and China). The accuracy of the original model to Latvia was 0.678 . The authors proposed seven modifications of the benchmark model, from one of which the accuracy was increased to 0.724 in the Latvian case. The dummies for the construction industry were estimated at $0.365-0.445$, showed that construction was an exceptionally risky industry.

Deloitte report (2008) showed that bankrupt companies were more engaged in fraudulent activities compared to non-bankrupt companies. In 1997, Statement on Auditing Standards [SAS] No. 82 identified the main fraud risk factors: the main of them is the abnormal changes in financial ratios and other non-financial data. According to the Sarbanes-Oxley legislation, it has been updated to SAS No. 99 in 2002. Thus, the first stage of an audit or examination begins with the detection of abnormal changes that entail deterioration in the financial position of the company. Owing to the development of computer technologies, using the data mining as an audit tool, the fraud variables based on disproportionate changes were developed in the studies by Beneish (1999), Lenard and Alam (2005), Skousen and Wright (2006) and others (Lenard \& Alam, 2009; Pustylnick, 2009).

Using the Altman's discriminant model as a prototype, Nugent (2003) modified the two of model coefficients to bankruptcy and fraud prediction: working capital to total assets was changed by shareholder equity; net sales to total assets - by revenue to total assets. As a result, the P-score model was created. Following Atman, Nugent and Beneish studies, Pustylnick $(2009,2011)$ established significant changes in time between the P-score and Z-score models. The P-score changes $[\Delta P]$ were higher than Z-score $[\Delta Z]$ in 29 cases when companies were involved in accounting scandals. The further studies by Pustylnick $(2016,2017)$ developed this technique.

\section{Research methodology}

\subsection{P-score approach}

The baseline of the present study is the P-score model used to identify fraud risk in financial statements, based on Pstylnick's studies $(2009,2011,2016,2017)$. According to a number of studies on the manifestation of earnings management through an increase in net accruals comparing to the direction of change of asset turnover and operating margin, Pustylnick (2016) used a similar approach to detect earnings manipulations. 
Pustylnick $(2009,2011)$ analyzed the changes of these ratios based on the Altman's Z-score model developed in 1968. He justified his choice of a model by a variety of studies, which determined the relationship between the Z-score and probability of earnings management use.

The Z-score formula is based on the financial results of the current year alone, but to get an insight into the company's financial performance, the practitioners analyze the data at least for two adjacent years (Pustylnick, 2017). The authors note that the auditors, forensic accountants and fraud examiners analyze the changes in the financial position of the company for at least three years. In practice, the Altman's model is the most popular for prediction of insolvency within auditors. 2014):

The original Altman's Z-score model has the following form (Altman, Iwanicz-Drozdovska, Laitinen, \& Suvas,

$$
Z=1.2 \cdot X_{1}+1.4 \cdot X_{2}+3.3 \cdot X_{3}+0.6 \cdot X_{4}+1.0 \cdot X_{5}
$$

where: $X_{1}=\frac{\text { Working capital }}{\text { Total assets }}$

$$
\begin{aligned}
& X_{2}=\frac{\text { Retained earnings }}{\text { Total assets }} ; \\
& X_{3}=\frac{\text { Earnings before interest and taxes }}{\text { Total assets }} ; \\
& X_{4}=\frac{\text { Market value of equity }}{\text { Book value of total liabilities }} ; \\
& X_{5}=\frac{\text { Sales }}{\text { Total assets }}
\end{aligned}
$$

In Pustylnick's studies $(2009,2011)$, the coefficient $\left(X_{5}\right)$ of Altman's Z-score models is presented differently: "sales" are replaced by "net sales".

To facilitate the perception of various coefficients in the model formulas, many of which are repeated, the authors of the present study entered their numbering of coefficients.

In his studies $(2009,2011)$, Pustylnick changed two coefficients in the Altman's Z-score model with two new, which were more represented variables to fraud detection by various scientific studies. More precisely, only numerators of the fractions were replaced. The numbers of coefficients were not changed.

The first new coefficient $\left(X_{6}\right)$ was the shareholders equity ratio that determined how much shareholders would receive in the event of company-wide liquidation. The second coefficient changed $\left(X_{7}\right)$ was the asset turnover ratio as a widely used independent variable in earnings management analysis. These two new coefficients were the potential indicators of fraud in financial performance. As a result, Pustylnick presented his own formula of P-score $(2009,2011)$ :

$$
P=1.2 \cdot X_{6}+1.4 \cdot X_{2}+3.3 \cdot X_{3}+0.6 \cdot X_{4}+1.0 \cdot X_{7},
$$

where: $X_{6}=\frac{\text { Shareholders equity }}{\text { Total assets }}$

$$
X_{7}=\frac{\text { Revenue }}{\text { Total assets }} .
$$

At the next stage, Pustylnick $(2009,2011)$ calculated the rates of changes in Z-score and P-score and compared them. The rate of change for $\mathrm{Z}$-score $(\Delta Z)$ and $\mathrm{P}$-score $(\Delta P)$ were calculated as follows:

$$
\begin{gathered}
\Delta Z=\frac{Z_{t}-Z_{t-1}}{\left|Z_{t-1}\right|} ; \\
\Delta P=\frac{P_{t}-P_{t-1}}{\left|P_{t-1}\right|} .
\end{gathered}
$$

Pustylnick's study (2009) showed that $\Delta P>\Delta Z$ for 24 companies out of 29 observed companies involved in some accounting scandals or $82.76 \%$ of all participants. In the next study (2011), Pustylnick revealed the median of this difference -0.37 , which was essential for determining the manipulations. 


\subsection{P-score and R-score}

In Pustylnick's study (2016), the coefficients that were different in the Z-score and P-score models $\left(X_{1}, X_{5}\right)$ and $\left(X_{6}, X_{7}\right)$ were included in the two individual models. Based on the studies about asset turnover and operating margin, the numerator of the fraction of Altmthe an Z-score model' coefficient $\left(X_{5}\right)$ was adjusted - sales were replaced by operating income $\left(X_{8}\right)$. Using the discriminant analysis the two linear functions were obtained - P-score and R-score.

In Pustylnick's study (2016), the new R-score model presents the Real Liquidity value of a company and modified P-score model presents the Perceived Wealth of a company.

The authors do not agree with Pustylnick regarding the name of value "Real Liquidity" calculated on the basis of the R-score since liquidity shows the ability to repay only short-term liabilities without guaranteeing a return on long-term investments. Furthermore, one of the main tasks of auditors is to bring the book value of assets and liabilities of the company to their real value in order to narrow the gap in investors' expectations. As a result, the authors of the present study suggest replacing the name of value "Real Liquidity" with "Real Wealth".

Based on Pustylnick's study (2016) and the authors' amendments, P-score and R-score are calculated as follows:
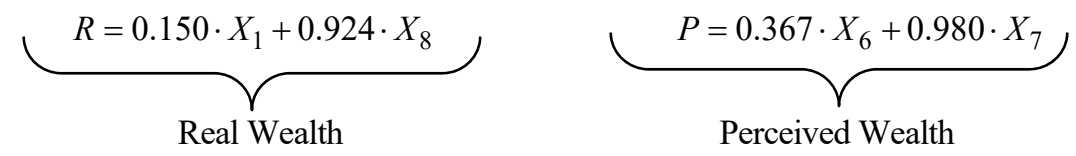

where: $X_{8}=\frac{\text { Operating income }}{\text { Total assets }}$.

The rate of change for R-score $(\Delta R)$ and P-score $(\Delta P)$ awas calculated similarly as in formula 3a and 3b:

$$
\begin{gathered}
\Delta R=\frac{R_{t}-R_{t-1}}{\left|R_{t-1}\right|}, \\
\Delta P=\frac{P_{t}-P_{t-1}}{\left|P_{t-1}\right|} .
\end{gathered}
$$

The results of Pustylnick's study (2016) established the joint occurrence of $\Delta P-\Delta R$ and Z-score. The companies with values of $|\Delta P-\Delta R|>0.3$ were more likely to be engaged in the manipulation with financial statements and these companies were more likely to have Z-score $<1$. In turn, the companies with Z-score $>3$ were less likely to have significant changes in financial statements and did not exhibit similar fluctuations of $\Delta P-\Delta R$. These results indicate that the P-score and $\mathrm{R}$-score approaches are applicable to companies on the verge of bankruptcy. The variable $X_{7}$ did not show the significance for fraud samples.

In the next study (2017), Pustylnick highlighted the potential of $\Delta P-\Delta R$ to indicate the manipulation with financial statements when they were significant. This method allowed identifying overstatement and underestimation of earnings. Continuing the study (Pustylnick, Temchenko \& Gubarkov, 2017), the authors examined the differences of $\Delta P-\Delta R$. The case of $\Delta P-\Delta R<-0.3$ indicated the upward earnings management and the case of $\Delta P-\mathrm{H} R>0.3$ indicated downward earnings management.

\subsection{The authors' approach}

In the present study, the Altman's model and its modifications serve as a backdrop for studying the development of possible solutions to the situation in the context of a deepening insolvency crisis over the period $\left(t_{n}-t_{n-1}\right)$.

The presented method of P-score and R-score is based on Altman's Z-score model, which is applicable to publicly traded companies. In 1983, Altman re-estimated the original model for the prediction of the bankruptcy of non-listed companies - Z'-score model (Altman, Iwanicz-Drozdovska, Laitinen \& Suvas, 2014):

$$
Z^{\prime}=0.717 \cdot X_{1}+0.847 \cdot X_{2}+3.107 \cdot X_{3}+0.420 \cdot X_{9}+0.998 \cdot X_{5} .
$$

The authors of the present article consider that this model might be preferred for using a P-score approach in the Latvian conditions, where most companies are non-listed.

In 1983, Altman also developed the Z'--score model for small companies, but it consisted only of four coefficients, without coefficient $\left(X_{5}\right)$ that is significant for using P-score method.

In 1998, the Altman's model was adapted to Latvian conditions by researches of Riga Technical University Shorin and Voronova (Shorin \& Voronova, 1998). The accuracy of this model has been tested several times (Scacun \& Voronova, 2018), and the applicability of this model has been verified in other countries. It is presented by the following formula: 


$$
Z^{L V}=-2.4+2.5 \cdot X_{1}+3.5 \cdot X_{2}+4.4 \cdot X_{10}+0.45 \cdot X_{9}+0.7 \cdot X_{5}
$$

where: $X_{10}=\frac{\text { Earnings beforetaxes }}{\text { Total assets }}$.

Considering the above-mentioned facts, the authors of the present study use various approaches to testing the P-score and Z-score approach.

Thus, the authors test three types of models to evaluate the company bankruptcy - Altman's Z-score and Z'- score models, Altman's model modification to Latvia - Shorin/xx xx's model. To indicate fraud in the company financial statements, the authors use P-score based on the Altman's Z-score, try to use their own approach based on the Altman's Z'-score models for private firms, Shorin/xxxxx's model for the Latvian companies, and Pustylnick's P-sore and $\mathrm{R}$-score version. The authors tested this method on the basis of the Latvian construction companies that failed due to recognised fraud.

Due to the fact that some variables used in the coefficients are not directly described in Pustylnick's studies, but these have the same nature in the accountancy legislation in different countries, the authors use several of them:

- In all bankruptcy evaluation models, two options of asset turnover ratio are used: the original ratio in Altman's model $\left(X_{5}\right)$, and the Pustylnick's modification $\left(X_{5}\right)$;

- In all fraud identification models, two options of revenue are used: the net turnover (sales, net sales) that is displayed in the first line of the Income Statement by the Latvian legislation; the revenue - all income, including the net turnover and other income of the income statement.

\section{Data samples}

The authors of the present study tested the practice of evaluating P-score and Z-score on a sample of 22 Latvian construction companies that failed due to recognised fraud.

The companies that went bankrupt due to fraud were selected by experts, related to fraud detection - investigators and prosecutors, insolvency administrators, auditors, and forensic accountants. The main data of these companies as the annual reports and the information of a company's registration were extracted from the Commercial Register of Latvia (2019) (see Figure 1). Other data as the fraud risk indicators, the illegal transactions, and the causes of bankruptcy fraud were determined in the investigation of the cases. The data for analysis were created by hand.

The construction companies selected for the study went bankrupt from 2001 to 2016. The period of the largest number of bankrupt companies coincided with the post-crisis period - 2009 and 2013.

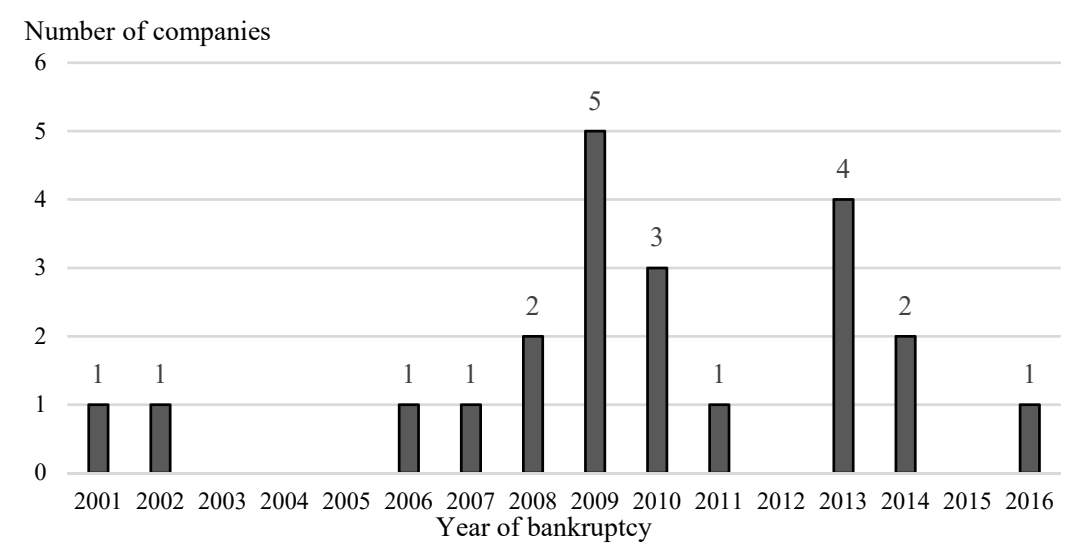

Figure 1. Bankrupt of Latvian construction companies due to fraud by years of bankruptcy

(source: created by the authors based on the Commercial Register of Latvia, 2019)

The period of company economy activity before bankruptcy ranged from 2 to 21 years. The most common age of companies until bankruptcy varied from 4 to 7 years, followed by 10 years; 3 companies were bankrupt after 18 and 21 years of commercial activity. Five of the observed companies were bankrupt before 3 years after registration that most likely was due to incompetence management of the fraud (Pervan \& Kuvek, 2013) (see Figure 2).

The lack of information on the use of P-score method for the two companies that were bankrupt up to 3 years after registration, and a company that did not submit annual reports, reduced the number of companies studied from 22 to 19. 


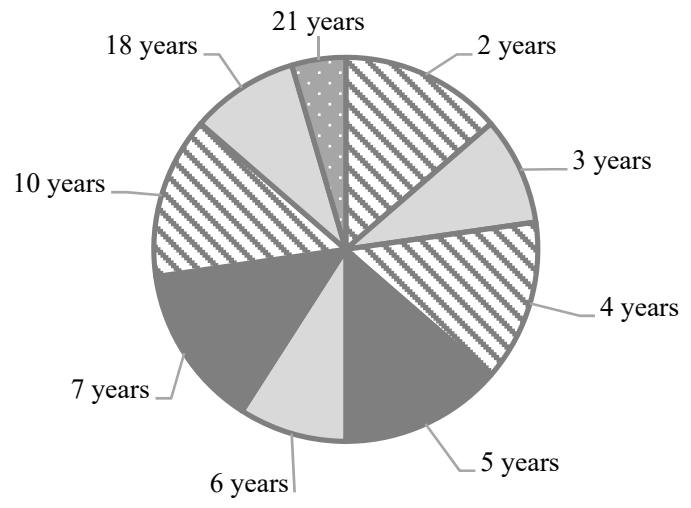

Figure 2. Bankrupt of Latvian construction companies due to fraud by years of activities before bankruptcy (source: created by the authors based on the Commercial Register of Latvia, 2019)

In accordance with the Law on Annual Financial Statements and Consolidated Financial Statements (Saeima, 2015), out of 19 companies studied, 10 are micro companies with assets of up to 350 thousand, a turnover of up to 700 thousand and an average number of employees up to 10;6 are small companies with assets of up to 4 million, a turnover of up to 8 million and an average number of employees up to 50; and 3 are medium-sized companies with assets of up to 20 million, a turnover of up to 40 million and an average number of employees up to 250; the annual financial statements of 8 companies were to be audited.

The financial characteristics of the considered companies are as follows: the average volume of a company's assets three years before insolvency varies from 75.6 thousand to 19.7 million; the average sales are from 0 to 38.1 million; the average number of employees is from 1 employee to 174 (see Figure 3 ).

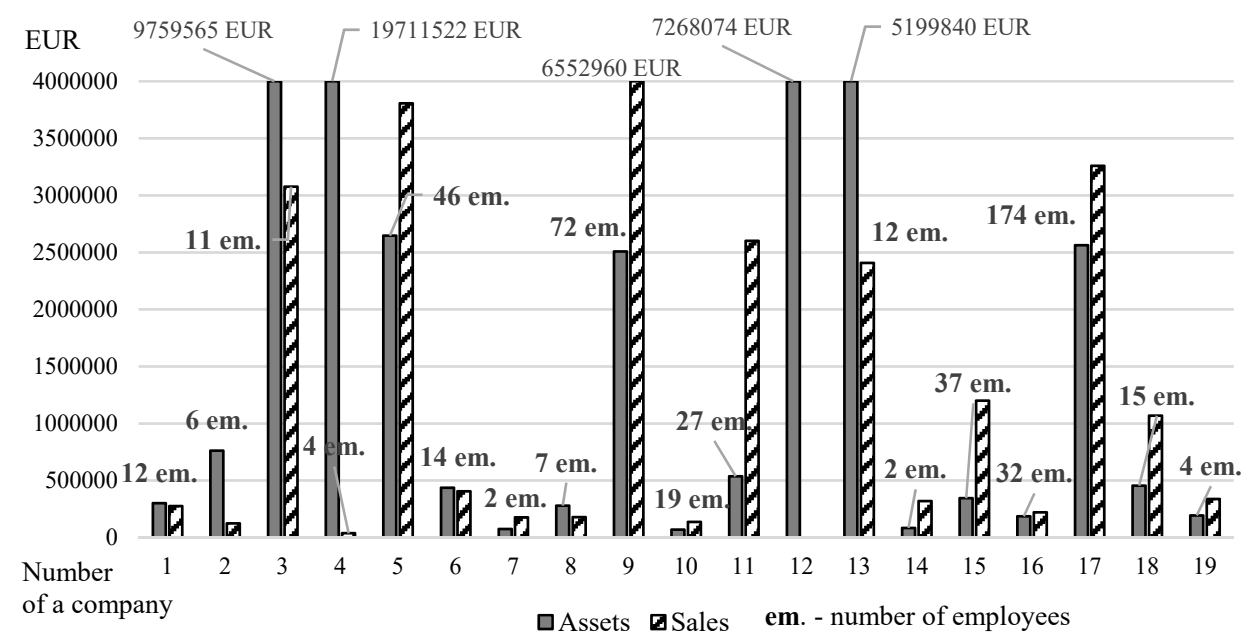

Figure 3. Bankrupt of Latvian construction companies due to fraud by assets and sales, number of employees (source: created by the authors based on company financial statements)

To present the types of fraud that the P-score model must identify, the authors disclose the fraud activities identified during the investigation process; and analyse the company annual reports and other known data by means of risk indicators based on SAS No. 99 (AICPA, 2002) and ISA No. 240 (IFAC, 2009). These indicators can be abnormal changes, manipulation with recognition of revenue and company's assets, incorrect management estimates, personal motives, etc.

Thus, the authors indicate four types of changes in a company's registration data, nine types of red flags in a company's financial statement, and seven kinds of causes of bankruptcy and its consequences. Nine types of fraud have been detected by experts during the investigation of each case of a company's bankrupt (see Table 1). 
Table 1. Fraud activities and risk signals for fraud investigation

(source: created by the authors based on analysis of company financial statements and expert conclusions)

\begin{tabular}{|c|l|l|l|l|}
\hline No. & $\begin{array}{c}\text { Changes in the company } \\
\text { registration data }\end{array}$ & \multicolumn{1}{|c|}{$\begin{array}{c}\text { Red flags in the company } \\
\text { financial statement }\end{array}$} & $\begin{array}{c}\text { Cause of bankruptcy and } \\
\text { it's consequences }\end{array}$ & \multicolumn{1}{|c|}{ Detected fraud } \\
\hline 1 & Address -13 & $\begin{array}{l}\text { A significant change in the } \\
\text { number of employees }-15\end{array}$ & Conflict with creditors -3 & Fictitious (bad) debts -17 \\
\hline 2 & Board -5 & Deals with related persons -11 & Conflict with clients -3 & Misstatements of the report \\
\hline 3 & Name of the company -3 & Executive or owner loans -11 & $\begin{array}{l}\text { Bankruptcy-related } \\
\text { company }-2\end{array}$ & Cash withdrawal -11 \\
\hline 4 & Shareholders -3 & The share of other debtors -6 & Business transfer -1 & No revenue recognition -5 \\
\hline 5 & - & Investment in intangible assets & Business completion -1 & Fictitious deals -5 \\
\hline 6 & - & Assignment of debts -4 & Raider seizure -1 & Cost overstatement -4 \\
\hline 7 & - & $\begin{array}{l}\text { The sharp decline in long-term } \\
\text { funds }-4\end{array}$ & $\begin{array}{l}\text { Conflict between board and } \\
\text { owners }-1\end{array}$ & $\begin{array}{l}\text { Unjustified write-off of as- } \\
\text { sets }-2\end{array}$ \\
\hline 8 & - & Assets revaluation -4 & Third party fraud -1 & Non-existent assets -2 \\
\hline 9 & - & Loans from owners or board -1 & Large tax audit fine -1 & Envelope wage -1 \\
\hline
\end{tabular}

Beside standards of audit, to indicate the non-financial indicators of fraudulent bankruptcy the authors used the results of their previous study (Liodorova \& Voronova, 2018).

\section{Result and discussion}

Using the Altman's Z-score and Z'-score models (Formula 1 and 6), and the Shorin/'s $Z^{\mathrm{LV}}$-score model (Formula 7), the authors evaluated the bankruptcy of study samples of Latvian construction companies (see Table 2).

Table 2. The results of Z-score, Z'-score and $Z^{\mathrm{LV}}$-score for the study samples a year before bankruptcy (source: created by the authors)

\begin{tabular}{|c|c|c|c|c|c|c|c|c|c|c|c|c|c|c|c|c|}
\hline $\begin{array}{c}\text { No of a } \\
\text { com- } \\
\text { pany }\end{array}$ & 1 & 3 & 4 & 5 & 6 & 7 & 8 & 11 & $\ldots$ & 17 & 18 & 20 & 21 & 22 & 2 & 9 \\
\hline \multirow{2}{*}{ Z-score } & 0.1 & 0.3 & 0.7 & -0.3 & -0.5 & -98.6 & 0.0 & -6.9 & $\ldots$ & 2.8 & 2.9 & 2.4 & 2.3 & 2.1 & 3.3 & 3.7 \\
\hline & \multicolumn{9}{|c|}{ DISTRESS $(\mathrm{Z}<1.8)$} & \multicolumn{7}{|c|}{ NO DISTRESS } \\
\hline \multirow{2}{*}{$\begin{array}{c}\text { Z'-score } \\
<1.23\end{array}$} & 0.3 & 0.2 & 0.4 & -0.1 & -0.1 & -84.8 & 0.2 & -5.3 & $\ldots$ & 2.7 & 3.1 & 1.9 & 2.2 & 1.9 & 2.1 & 3.4 \\
\hline & \multicolumn{9}{|c|}{ DISTRESS $(Z<1.2)$} & \multicolumn{7}{|c|}{ NO DISTRESS } \\
\hline \multirow{2}{*}{$\begin{array}{l}\mathrm{Z}^{\mathrm{LV}}- \\
\text { score }\end{array}$} & -3.3 & -2.2 & -1.1 & -3.5 & -3.9 & -176.7 & -3.1 & -14.3 & $\cdots$ & 0.6 & -0.2 & 0.1 & 0.1 & 0.7 & 2.6 & 1.8 \\
\hline & \multicolumn{14}{|c|}{ DISTRESS $(Z<1.8)$} & \multicolumn{2}{|c|}{ ND } \\
\hline
\end{tabular}

The best result showed the Shorin/'s model (Formula 7). The $\mathrm{Z}^{\mathrm{LV}}$-score model identified the bankruptcy for 18 companies from 20 companies studied that submitted reports a year before bankruptcy. The accuracy of the Shorin/'s $\mathrm{Z}^{\mathrm{LV}}$-score model is $90.0 \%$ compared with the accuracy of both Altman's Z-score and Z'-score models calculated for $65.0 \%$.

Table 3. Statistical characteristics of Z-score, $Z^{\prime}$-score and $Z^{\mathrm{LV}}$-score for the study samples a year before bankruptcy (source: created by the authors)

\begin{tabular}{|c|c|c|c|}
\hline Variables & Z-score & Z'-score & ZLV-score \\
\hline Average of the score for all companies & -4.7 & -3.8 & -11.5 \\
\hline Average of the score in the detected distress & -8.7 & -7.2 & -13.1 \\
\hline Extreme value of the score of detected distress & -98.6 & -84.8 & -176.7 \\
\hline Average of detected distress without extreme value & -1.2 & -0.7 & -3.4 \\
\hline Maximum of distress detected & -6.9 & -5.3 & -14.3 \\
\hline Minimum of distress detected & 0.7 & 0.4 & 0.7 \\
\hline Median of distress detected & -0.3 & -0.1 & -2.8 \\
\hline Standard deviation & 2.2 & 1.7 & 4.1 \\
\hline Accuracy of detected distress & $65.0 \%$ & $65.0 \%$ & $\%$ \\
\hline
\end{tabular}


The average score for all companies studied is -4.7 to $Z$-score, -3.8 to $Z^{\prime}$-score, and -11.5 to $Z^{\mathrm{LV}}$-score. An abnormal Z-score is calculated for a company, respectively Z-score was $-98.6, Z^{\prime}$-the score was $-84.8, Z^{\mathrm{LV}}$-score is -176.7. Thus, the following characteristics of $Z$ were calculated without this extreme value (see Table 3).

At the next stage of this study, the authors tested the P-score method in eleven ways. To calculate Z-score and Pscore the authors use different formulas and different coefficients in these formulas, for example:

- Way 1 - formulas 1 and 2. In formula 2, the fraction numerator of coefficient $\left(X_{7}\right)$ or revenue is calculated as all income (including the net turnover and other income of the income statement);

- Way 2 - formulas 1 and 2. In formula 1, the fraction numerator of coefficient $\left(X_{5}\right)$ or sales is replaced to operating income or coefficient $\left(X_{8}\right)$; in formula 2 , the fraction numerator of coefficient $\left(X_{7}\right)$ or revenue is calculated as a sale or net turnover by the Latvian legislation;

- Way 3 - formulas 1 and 2. In formula 1, the fraction numerator of coefficient $\left(X_{5}\right)$ or sales is replaced to operating income or coefficient $\left(X_{8}\right)$; in formula 2 , the fraction numerator of coefficient $\left(X_{7}\right)$ or revenue is calculated as all income (read more in detail the part 1.3 "The authors' approach).

The accuracy of the method using a bunch of changes $\Delta \mathrm{Z}$ and $\Delta \mathrm{P}$ is as follows: using the original Z-score $(\Delta \mathrm{Z})-$ 42.1\% (see Formulas 2 and 1; Formulas 3a and 3b); using Z'-score modification ( $\Delta Z^{\prime}$ ) $-47.4 \%$ (Formula 6 and Formula 1 with numerical factors of Formula $6 ; 3 \mathrm{a}$ and $3 \mathrm{~b}$ ); using Latvian $\mathrm{Z}^{\mathrm{LV}}$-score modification $\left(\Delta \mathrm{Z}^{\mathrm{LV}}\right)-52.6 \%$ (Formula 7 and Formula 1 with numerical factors of Formula 7; Formulas $3 a$ and 3b) (see Table 4).

All three approaches revealed fraud in four cases - for companies No. 1, 4, 15, and 16, in which Z-score was less than 1.8, indicating bankruptcy. All these approaches did not reveal fraud for companies No. 2 and 9, in which Z-score was higher than 3, without predicting the onset of bankruptcy. Fraud has not been identified for companies No. 11 and 19 with Z-score more less than 0. Two of the three approaches revealed fraud for five companies in the "grey zone", based on an estimate of Z-score from 1.8 to 3. Fraud has not been identified for two companies with Z-score less than 0 (see Table 4).

Table 4. The results of a bunch of changes $\Delta \mathrm{P}$-score and $\Delta \mathrm{Z}$-score for the study samples a year before bankruptcy (source: created by the authors)

\begin{tabular}{|c|c|c|c|c|c|c|c|c|c|}
\hline \multirow{2}{*}{ Z-score } & \multirow{2}{*}{$\begin{array}{l}\text { No. of a } \\
\text { company }\end{array}$} & $\Delta \mathrm{P}-\Delta \mathrm{Z}$ & $\Delta \mathrm{P}-\Delta \mathrm{Z}$ & $\Delta \mathrm{P}-\Delta \mathrm{ZLV}$ & \multirow{2}{*}{ Z-score } & \multirow{2}{*}{$\begin{array}{l}\text { No. of a } \\
\text { company }\end{array}$} & \multirow{2}{*}{\begin{tabular}{|c|}
$\Delta \mathrm{P}-\Delta \mathrm{Z}$ \\
Formula 1
\end{tabular}} & \multirow{2}{*}{$\begin{array}{c}\Delta \mathrm{P}-\Delta \mathrm{Z}^{\prime} \\
\text { Formula } 6\end{array}$} & \multirow{2}{*}{$\frac{\Delta \mathrm{P}-\Delta \mathrm{ZLV}}{\text { Formula } 7}$} \\
\hline & & Formula 1 & Formula 6 & Formula 7 & & & & & \\
\hline \multicolumn{5}{|c|}{ Results are equal for all three approaches } & \multicolumn{5}{|c|}{ Results are equal for two of the three approaches } \\
\hline $\mathrm{Z}<1.8$ & \multicolumn{4}{|c|}{\begin{tabular}{|l} 
Revealed fraud \\
\end{tabular}} & $1.8<\mathrm{Z}<3$ & \multicolumn{4}{|c|}{ Revealed fraud } \\
\hline 0.1 & 1 & 0.3 & 2.3 & -0.4 & 2.77 & 17 & 0 & 0.1 & 3.2 \\
\hline 0.7 & 4 & 6.7 & 1.7 & 0.3 & 2.86 & 18 & 0.1 & 0.1 & 21.8 \\
\hline-0.2 & 15 & 1.1 & 3.7 & 0.6 & 2.38 & 20 & 0.1 & 0.1 & 48.8 \\
\hline \multirow[t]{2}{*}{-0.4} & 16 & 1.0 & 88.7 & 1.1 & 2.33 & 21 & 0 & 0 & -31.8 \\
\hline & & & & & 2.12 & 22 & -0.1 & -0.1 & 0.5 \\
\hline $\mathrm{Z}<0$ & \multicolumn{4}{|c|}{ Fraud not revealed } & $Z<0$ & \multicolumn{4}{|c|}{ Fraud not revealed } \\
\hline-6.8 & 11 & 0 & 0 & 0 & -98.6 & 7 & -130.3 & 0 & 0 \\
\hline-4.2 & 19 & 0 & 0 & 0 & -2.5 & 14 & 0.1 & -1.1 & -0.1 \\
\hline$Z>3$ & \multicolumn{4}{|c|}{ Fraud not revealed } & & & & & \\
\hline 3.29 & 2 & 0 & 0 & -0.1 & Fraud & & 8 cases & 9 cases & 10 cases \\
\hline 3.68 & 9 & 0 & 0 & -0.1 & Accuracy & & $42.1 \%$ & $47.4 \%$ & $52.6 \%$ \\
\hline
\end{tabular}

The highest accuracy of fraud identification 94.7\% showed Pustylnick's P-score and R-score approach (see Formula 4, 5a, and 5b), which detected fraud for 18 companies from 19 companies submitted the financial statements (see Table 5).

The Latvian modification of P-score is the second for the accuracy of fraud detection $-89.5 \%$ in original Pustylnick's method. However, the revenue calculation as all income in the fraction numerator of the coefficient $\left(X_{7}\right)$ in Pthe -score approach increased the detection accuracy of Lthe atvian model to Pustylnick's result - 94.7\% (see Table 5).

The differences between Pustylnick's and Latvian modification results were in three cases: company No. 2 and No. 9 with Z-score above 3, and in company No. 22, located in the "grey zone".

The results of the tests showed a relationship between Z-score and identified fraud only for bankrupt companies, which Z-score is less than 3, but is higher than 0 . The authors do not recommend to use the P-score approach for non-bankrupt companies with Z-score above 3 . Unfortunately, especially problematic companies, which Z-score is much less 0 , are shown the ambiguous results in identifying fraud. The authors describe this fact as an excess of the seriousness of the existing financial problems (bankruptcy) over possible fraud. 
Table 5. The results of $\Delta \mathrm{P}$ and $\Delta \mathrm{R}$-score, $\Delta \mathrm{P}$ and $\Delta \mathrm{Z}^{\mathrm{LV}}$-score for the study samples using the different coefficient $\left(X_{7}\right)$ (source: created by the authors)

\begin{tabular}{|c|c|c|c|c|c|c|c|c|c|}
\hline \multirow{2}{*}{$\begin{array}{l}\text { No of } \\
\text { company }\end{array}$} & \multicolumn{2}{|c|}{$\begin{array}{c}\Delta \mathrm{P} \text {-score }-\Delta \mathrm{R} \text {-score } \\
\text { Formulas } 4 \\
\end{array}$} & \multicolumn{2}{|c|}{$\begin{array}{c}\Delta \mathrm{P} \text {-score }-\Delta \mathrm{ZLV} \text {-score } \\
\text { Formula } 7 \text { with }\left(X_{8}\right)\end{array}$} & \multirow{2}{*}{$\begin{array}{c}\text { No of } \\
\text { company }\end{array}$} & \multicolumn{2}{|c|}{$\begin{array}{c}\Delta \mathrm{P} \text {-score }-\Delta \mathrm{R} \text {-score } \\
\text { Formulas } 4\end{array}$} & \multicolumn{2}{|c|}{$\begin{array}{c}\Delta \mathrm{P} \text {-score }-\Delta \mathrm{ZLV} \text {-score } \\
\text { Formula } 7 \text { with }\left(X_{8}\right)\end{array}$} \\
\hline & $\left(\begin{array}{c}X_{7} \\
\text { Sales }\end{array}\right)$ & $\left(\begin{array}{c}X_{7} \\
\text { All income }\end{array}\right)$ & $\left(\begin{array}{c}X_{7} \\
\text { Sales }\end{array}\right)$ & $\left(\begin{array}{c}X_{7} \\
\text { All income }\end{array}\right)$ & & $\left(\begin{array}{c}X_{7} \\
\text { Sales }\end{array}\right)$ & $\left(\begin{array}{c}X_{7} \\
\text { All income }\end{array}\right)$ & $\left(\begin{array}{c}X_{7} \\
\text { Sales }\end{array}\right)$ & $\left(\begin{array}{c}X_{7} \\
\text { All income }\end{array}\right)$ \\
\hline 1 & 5.5 & 5.4 & 2.6 & 3.6 & 13 & \multicolumn{2}{|c|}{ n.d. } & \multicolumn{2}{|c|}{ n.d. } \\
\hline 2 & 0.4 & 0.3 & 0.7 & -2.2 & 14 & 1.1 & 1.1 & 8.1 & 15.3 \\
\hline 3 & 25.4 & 25.4 & -0.2 & 2.3 & 15 & 3.9 & 8.9 & 0.4 & 2.8 \\
\hline 4 & 0.7 & 0.6 & -1.3 & 1.1 & 16 & 1.9 & 2.0 & 2.5 & 4.0 \\
\hline 5 & 2.7 & 2.7 & 1.5 & 3.2 & 17 & 5.1 & 5.1 & 2.4 & -7.9 \\
\hline 6 & 1.9 & 1.9 & 1.9 & 4.6 & 18 & 2.1 & 2.1 & 4.3 & -1.3 \\
\hline 7 & 2.0 & 2.0 & 13.7 & 350.7 & 19 & -8.0 & -9.3 & 0.7 & 10.1 \\
\hline 8 & 10.7 & 10.7 & 1.6 & 2.8 & 20 & 5.3 & 5.3 & 1.7 & -1.4 \\
\hline 9 & 0.2 & 0.2 & 2.6 & 0.5 & 21 & -1.0 & -1.0 & 1.6 & -35.2 \\
\hline 10 & \multicolumn{2}{|c|}{ n.d. } & \multicolumn{2}{|c|}{ n.d. } & 22 & 0.4 & 0.4 & -0.2 & 0.2 \\
\hline 11 & -3.6 & -3.5 & 1.8 & 15.4 & Fraud & 18 cases & 18 cases & 17 cases & 18 cases \\
\hline 12 & \multicolumn{2}{|c|}{ n.d. } & \multicolumn{2}{|c|}{ n.d. } & Accuracy & $94.7 \%$ & $94.7 \%$ & $89.5 \%$ & $94.7 \%$ \\
\hline
\end{tabular}

In general, all tested approaches showed the common results that means the feasibility of this method used for bankruptcy fraud detection in Latvia (see Figure 4).

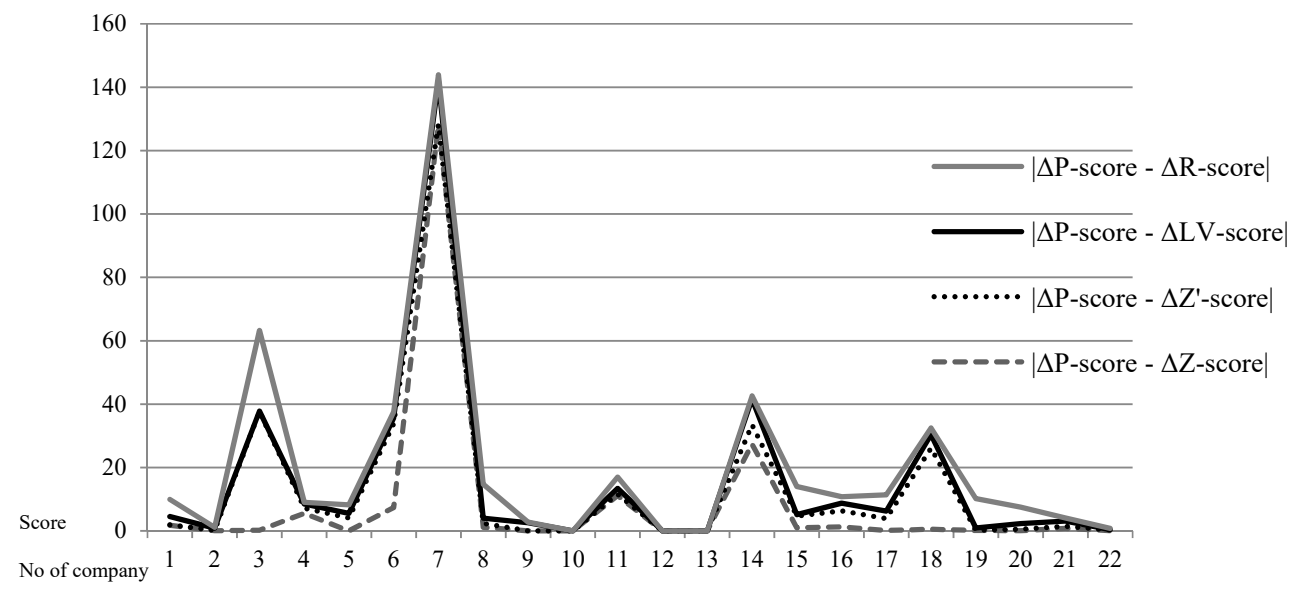

Figure 4. The results of $\Delta \mathrm{P}$ and Z-score, $\Delta \mathrm{Z}$ '-score and $\Delta \mathrm{Z}^{\mathrm{LV}}$-score, $\Delta \mathrm{R}$-score use for the study samples a year before bankruptcy (source: created by the authors)

Figure 4 shows the results of using the coefficient $\left(X_{8}\right)$ in Z-score models and coefficient $\left(X_{7}\right)$ in the P-score model modifications.

Using the coefficient $\left(X_{7}\right)$ as a sales and all income, the average modules of $|\Delta \mathrm{P}-\Delta \mathrm{R}|$ for all companies studied are similar; respectively they are 4.6 and 4.3 to R-score. However, the average modules of $\left|\Delta \mathrm{P}-\Delta \mathrm{Z}^{\mathrm{LV}}\right|$ are not similar - 2.6, when $\left(X_{7}\right)$ is calculated as a sales, and 24.4, when $\left(X_{7}\right)$ is calculated as all incomes. There is not sigthe nifant influence of an abnormal Z-score to the $|\Delta \mathrm{P}-\Delta \mathrm{R}|$ compared to the influence of this anomaly to $\left|\Delta \mathrm{P}-\Delta \mathrm{Z}^{\mathrm{LV}}\right|$ (see Table 6).

Despite the different approaches in methods and calculation of coefficient $\left(X_{7}\right)$, the medians of modules are similar from 1.7 to $3.0\left(\mathrm{Z}^{\mathrm{LV}}\right.$-score), 2.4 in the both $\mathrm{R}$-score approach. The smallest and largest deviations are indicated to $\mathrm{Z}^{\mathrm{LV}}$-score -1.8 for coefficient $\left(X_{7}\right)$ as the sales, 8.6 for $\left(X_{7}\right)$ as the all incomes; the standard deviations to R-score in both cases are similar - 6.1 and 6.0. According to Pustylnick, Temchenko and Gubarkov study (2017), the coefficient ( $\left.X_{7}\right)$ is not so signifant as others three variables to use the P-score method. 
Table 6. Statistical characteristics for $|\Delta \mathrm{P}-\Delta \mathrm{R}|$ and $\left|\Delta \mathrm{P}-\Delta \mathrm{Z}^{\mathrm{LV}}\right|$ for the study samples using the different coefficient $\left(X_{7}\right)$ (source: created by the authors)

\begin{tabular}{|l|c|c|c|c|}
\hline \multirow{2}{*}{ Variables } & \multicolumn{2}{|c|}{$\mid \Delta \mathrm{P}$-score $-\Delta \mathrm{R}$-score $\mid$} & \multicolumn{2}{c|}{$\mid \Delta \mathrm{P}$-score $-\Delta$ ZLV-score $\mid$} \\
\cline { 2 - 5 } & $\left(X_{7}\right.$ Sales $)$ & $\left(X_{7}\right.$ All income $)$ & $\left(X_{7}\right.$ Sales $)$ & $\left(X_{7}\right.$ All income $)$ \\
\hline Average of the differences for all companies & 4.6 & 4.3 & 2.6 & 24.4 \\
\hline Differences to extreme value of the score distress & 2.0 & 2.0 & 13.7 & 350.7 \\
\hline Average of detected distress without extreme & 4.8 & 4.4 & 2.0 & 6.3 \\
\hline Maximum of distress detected & 25.4 & 25.4 & 8.1 & 35.2 \\
\hline Minimum of distress detected & 0.2 & 0.2 & 0.2 & 0.2 \\
\hline Median of distress detected & 2.4 & 2.4 & 1.7 & 3.0 \\
\hline Standard deviation & 6.1 & 6.0 & 1.8 & 8.6 \\
\hline Accuracy of detected distress & $94.7 \%$ & $94.7 \%$ & $89.5 \%$ & $94.7 \%$ \\
\hline
\end{tabular}

To testify the results, the authors tested the P-score method on five Latvian construction companies declared insolvent in 2018, about which there is no evidence of fraud (No. B1-B5), and on five Latvian construction companies that were active at the time of this writing (No. A1-A5). The results for insolvent companies were provided based on financial statements for the year for bankruptcy; for active companies - according to the financial statements for 2017 (see Table 7).

Table 7. The results of a bunch of changes $\Delta \mathrm{P}$-score and $\Delta \mathrm{Z}$-score for the test samples (source: created by the authors)

\begin{tabular}{|c|c|c|c|c|c|c|c|c|c|}
\hline \multirow{2}{*}{ Z-score } & \multirow{2}{*}{$\begin{array}{l}\text { No. of a } \\
\text { company }\end{array}$} & $\Delta \mathrm{P}-\Delta \mathrm{Z}$ & $\Delta \mathrm{P}-\Delta \mathrm{Z}$ & $\Delta \mathrm{P}-\Delta \mathrm{ZLV}$ & \multirow{2}{*}{ Z-score } & \multirow{2}{*}{$\begin{array}{l}\text { No. of a } \\
\text { company }\end{array}$} & $\Delta \mathrm{P}-\Delta \mathrm{Z}$ & $\Delta \mathrm{P}-\Delta \mathrm{Z}^{\prime}$ & $\Delta \mathrm{P}-\Delta \mathrm{ZLV}$ \\
\hline & & Formula 1 & Formula 6 & Formula 7 & & & Formula 1 & Formula 6 & Formula 7 \\
\hline \multicolumn{5}{|c|}{ Failed companies } & \multicolumn{5}{|c|}{ Active companies } \\
\hline \multicolumn{5}{|c|}{ Fraud risk not revealed } & \multicolumn{5}{|c|}{ Fraud risk not revealed } \\
\hline 7.2 & $\mathrm{~B} 2$ & 0 & 0 & 0 & 3.4 & A1 & 0.1 & 0 & 0.1 \\
\hline 2.7 & B3 & 0 & 0 & 0.3 & 5.0 & A3 & 0 & 0 & 3.3 \\
\hline-2.0 & B5 & 0 & 0 & 0 & 2.4 & A4 & 0 & 0 & -1.4 \\
\hline 2.5 & B4 & 0.1 & 0 & -0.5 & 2.3 & A5 & 0 & 0 & 1.6 \\
\hline \multicolumn{5}{|c|}{ Fraud risk identified } & \multicolumn{5}{|c|}{ Fraud risk identified } \\
\hline-0.4 & B1 & 0.8 & -0.7 & -2.0 & 2.0 & A2 & 0.3 & 0.1 & 1.0 \\
\hline
\end{tabular}

The test samples showed the same results as compared with the results of study samples, based on the Latvian construction companies, which failed as a result of the recognized fraud. Financial data of companies with Z-score above 3 do not reveal possible fraud (companies No. B124, A1 and A3), as well as especially problematic companies, which Z-score is much less 0 (company No. B5).

However, using the P-score method, fraud risk was identified for the company with Z-score of less than 3 (company No. A2), and more precisely, for the companies with Z-score of less than 1.8, but not much less than 0 (company No. B1).

\section{Conclusions}

The P-score method for fraud detection in the financial statements is based on the Altman's Z-score background for bankruptcy prediction. The authors of this study tested the P-score and Z-score models to detect fraudulent bankruptcy in regional conditions, based on annual reports of the Latvian construction companies that failed due to fraud. The authors used different modifications of Z-score, such as an original version of Z-score, the modified Z'-score for small and medium-sized companies and its modification for Latvian companies $-\mathrm{Z}^{\mathrm{LV}}$-score.

The findings of the present study have shown the possibility of using the P-score and Z-score technique for bankruptcy fraud detection in the Latvian companies, based on the construction sector samples. It has been the first test of practical implication of P-score model in Latvia and the Baltic countries. As a result, all tested approaches have demonstrated the common results that indicate the feasibility of this method for bankruptcy fraud detection.

The accuracy of the method using a bunch of changes $\Delta \mathrm{Z}$ and $\Delta \mathrm{P}$ on the study samples was $42.1 \%$ for original Z-score model, $47.4 \%$ for $Z$ ' -score and $52.6 \%$ for the Latvian $\mathrm{Z}^{\mathrm{LV}}$-score modifications. The accuracy of $\Delta \mathrm{R}$ and $\Delta \mathrm{P}$ method is about $90.0 \%$ in the Pustyknick and the Latvian versions. In all modifications of P-score, the accuracy of the method can be improved depending on the calculation of the coefficient containing the revenue indicator. 
The study has shown that regional models more accurately reveal both bankruptcy and financial manipulations. The study has revealed some differences in the calculation of the coefficient associated with the used terminology of accounting - revenue, sale, and turnover.

Using the P-score method, fraud risk can be identified for the companies in the "grey zone" with Z-score of less than 3 , and more precisely, for the companies with Z-score of less than 1.8, but not much less than 0 . The authors do not recommend to use the P-score approach for companies with Z-score above 3. Unfortunately, especially problematic companies, which Z-score is significantly less than 0 , are showed the ambiguous results in identifying fraud. The authors describe this fact as an excess of the seriousness of the existing financial problems (bankruptcy) over possible fraud.

The authors note that the P-score method can be used as a tool to identify fraud risk as one of the possible solutions to a company's bankruptcy. A thorough check should be used to prove the fact of fraud as evidence to the court, using auditing and forensic accounting tools, investigation approaches. However, this method may facilitate the initial investigation.

The results of the study can be used by auditors, investors, partners and forensic accountants to detect fraud in the company's financial statements in order to protect investors and ensure repayment of payables.

The further researches should be aimed at increasing the sample to test the method, including the samples from different industries, non-bankrupt companies and random companies.

\section{References}

Altman, E., Iwanicz-Drozdowska, M., Laitinen, E., \& Suvas, A. (2014). Distressed firm and bankruptcy prediction in an international context: a review and empirical analysis of Altman's Z-score model. SSRN. https://doi.org/10.2139/ssrn.2536340

American Institute of Certified Public Accountants [AICPA]. (2002). Statement on Auditing Standards No. 99: Consideration of Fraud in a Financial Statement Audit. Retrieved from https://www.aicpa.org/Research/Standards/AuditAttest/ DownloadableDocuments/AU-00316.pdf

Association of Certified Fraud Examiners [ACFE]. (2018). Report to the nation. Retrieved from https://s3-us-west-2.amazonaws.com/acfepublic/2018-report-to-the-nations.pdf

Beneish, M. (1999). The detection of earnings manipulation. Financial Analysts Journal, 55(5), 24-36. https://doi.org/10.2469/faj.v55.n5.2296

Central Statistical Bureau of Latvia. (2019). Latvija. Statistics in Brief 2018. Retrieved from https://www.csb.gov.lv/en/statistics/ statistics-by-theme/economy/GDP/search-in-theme/298-Latvia-statistics-brief-2018

Commercial Register of Latvia. (2019). MNP registration notikumi pec notikuma data. Retrieved from https://ws.ur.gov.lv/urpubl?act=MNR_STAT\&stat_id=531\&tablesequence=\&tablepage

Deloitte. (2008). Ten things about bankruptcy and fraud. Retrieved from https://bankruptcyfraud.typepad.com/ Deloitte_Report.pdf

International Federation of Accountants [IFAC]. (2009). International Standard on Audit No. 240: The Auditor's Responsibilities Relating to Fraud in an Audit of Financial Statements. Retrieved from http://www.ifac.org/system/files/downloads/a0122010-iaasb-handbook-isa-240.pdf

Latvian Construction Contractor Partnership. (2017). Construction industry review 2017. Buvnieciba Latvija. Ilgtspejas izaicinajumi. Retrieved from http://www.latvijasbuvnieki.lv/research/buvniecibas-nozares-parskats-2017/

Lenard, M., \& Alam, P. (2009). A historical perspective on fraud detection: from bankruptcy models to most effective indicators of fraud in recent incidents. Journal of Forensic \& Investigative Accounting, 1(1), 1-27. https://doi.org/10.4018/978-1-59140553-5.ch026

Lenard, M., \& Alam, P. (2005). Application of fuzzy logic to fraud detection. In M. Khosrow-Pour (Ed.), Encyclopedia of Information Science and Technology (pp. 135-139). Idea Group.

Liodorova, J., \& Voronova, I. (2018). The integral system of fraudulent bankruptcy valuation. Social Sciences Bulletin, 2(27), 4260.

Mackevičius, J., \& Rakšteliene, A. (2005). Employing Altman's model to predict the bankruptcy of Lithuanian companies. Monetary Studies, 1, 24-42.

Marcinkevičius, R., \& Kanapickiene, R. (2014). Bankruptcy prediction in the sector of construction in Lithuania. Proceedia-Social and Behavioral Sciences, 156, 553-557. https://doi.org/10.1016/j.sbspro.2014.11.239

Nugent, J. (2003). Plan to Win: Analytical and operations tools - gaining competitive advantage (2 ${ }^{\text {nd }}$ ed.). USA: McGraw Hill.

Pervan, I., \& Kuvek, T. (2013). The relative importance of financial ratios and nonfinancial variables in predicting of insolvency. Croatian Operational Research Review, 4, 187-198.

Pustylnick, I. (2009). The combined algorithm of detection of manipulation in financial statements. SSRN. https://doi.org/10.2139/ssrn.1422693

Pustylnick, I. (2011). The empirical algorithm of detection of manipulation with financial statements. Journal of Accounting, Finance and Economics, 1(2), 54-57.

Pustylnick, I. (2016). Using Z-score in the detection of revenue manipulations. Smart and Efficient Economy: Preparation for the Future Innovative Economy (pp. 62-69). Brno, Czech Republic: the Brno University of Technology, Faculty of Bussiness and Management. http://www.icem.lt/public/icem/ICEM_2016_selected\%20papers.pdf

Pustylnick, I. (2017). Comparison of liquidity based and financial performance based indicators in financial analysis. Oeconomia Copernicana, 8(1), 83-97. https://doi.org/10.24136/oc.v8i1.6 
Pustilnick, I., Temchenko, O., \& Gubarkov, S. (2017). Estimating the influence if accounting variables change on earning management detection. Journal of International Studies, 10(1), 110-122. https://doi.org/10.14254/2071-8330.2017/10-1/7

Saeima. (2015). Law on annual financial statements and consolidated financial statements. Latvijas Vestnesis, 222(5540). Retrieved from https://likumi.lv/ta/en/en/id/277779

Sartaputna, S., \& Mietule, I. (2018). The construction sector role in the economy of Latvia. Individual. Society. State (pp. 97-101). Rezekne, Latvia: Rezekne Academy of Technologies.

Sauka, A. (2018). Enu ekonomika Latvijas buvniecibas nozare 2015-2017. Retrieved from http://www.latvijasbuvnieki.lv/research /petijums-enu-ekonomika-Latvijas-buvniecibas-nozare-2015-2017/

Scacun, N., \& Voronova, I.(2018). Evaluation of enterprise survival: the case of Latvian enterprises. Business, Management and Education, 16(1), 13-26. https://doi.org/10.3846/bme.2018.2482

Shorin, R., \& Voronova, I. (1998). Uznemuma maksatnespejas novertejums. Ekonomiskas problemas uznemejdarbiba, 125-131. Riga, Latvia: Riga Technical University.

Skribans, V., \& Pocs, R. (2008). Latvian construction branch development forecasting model. Munich Personal RePEc Archive paper No. 20360. https://mpra.ub.uni-muenchen.de/20360/1/MPRA_paper_20360.pdf

Skousen, C., \& Wright, C. (2006). Contemporaneous risk factors and the prediction of financial statement fraud. SSRN. https://doi.org/10.2139/ssrn.938736 